\title{
Russia in the World Ocean: Interests and Lines of Presence
}

\author{
A. G. Druzhinin ${ }^{a, b}, *$ and S. S. Lachininskii ${ }^{c, d, * *}$ \\ ${ }^{a}$ Southern Federal University, Rostov-on-Don, 344006 Russia \\ ${ }^{b}$ Institute of Geography, Russian Academy of Sciences, Moscow, 119017 Russia \\ ${ }^{c}$ St. Petersburg State University, St. Petersburg, 199034 Russia \\ ${ }^{d}$ Institute for Problems of Regional Economics, Russian Academy of Sciences, St. Petersburg, 190013 Russia \\ *e-mail: alexdru9@mail.ru \\ **e-mail: lachininsky@gmail.com
}

Received August 7, 2020; revised April 13, 2021; accepted April 21, 2021

\begin{abstract}
One of the modern global trends is the accelerated formation of a "blue economy" based on transport and logistics, resource and raw materials, and other opportunities of the seas and oceans, which occupy more than $70 \%$ of the Earth's surface. The article substantiates the growth in the importance of maritime economic activity for the Russian Federation and emphasizes the peculiarities of realizing its interests in the World Ocean, taking into account foreign policy, marketing and economic, technical and technological, financial and investment, infrastructural, and institutional opportunities and limitations. Attention is focused on the factors and features of the dynamics and spatial localization of such important industries for Russia as seaports and logistics, hydrocarbon production on sea shelves, production and processing of marine biological resources, shipbuilding, and coastal industry. It is shown that, on the one hand, Russia's sphere of potential (declared) interests is the waters of the entire World Ocean and, on the other, the country's maritime activity has a predominantly Circumeurasian (delimiting the mainland confined to its marginal seas) character, consistently shifting (under the influence of climatic, market, and geopolitical factors) into the Arctic, as well as the coastal zones and water areas of the Far East. The maritime interests of the leading Russian companies (Gazprom, Rosneft, Lukoil, NOVATEK, Rosatom and Rosatomflot, Sovkomflot, Norilsk Nickel, etc.) are emphasized, an inventory of limiting factors and the risks of further maritime orientation of the Russian economy has been compiled, and the most important areas of Russia's presence in regions of the World Ocean in conditions of growing geopolitical turbulence and geoeconomic competition are identified. As specific results, we should single out the well-substantiated priority directions of Russia's presence in the World Ocean, as well as the main priorities and directions for building up an effective Russian presence there. The identified limiting factors and limitations of maritime activity in modern Russia are of particular interest.
\end{abstract}

Keywords: World Ocean, Russia, geoeconomics, geopolitics, maritime interests, coastal regions, blue economy, Russian corporations, maritime activity

DOI: $10.1134 /$ S2079970521030035

\section{INTRODUCTION AND FORMULATION OF THE PROBLEM}

The World Ocean and coastal zones closely associated with it have historically been a priority arena for global competition, cooperation, and the creation of new value. In the second half of the 19th century, Alfred T. Mahen, in his famous book The Influence of Sea Power on History (1660-1783), argued that possession or control over the ocean and its use is now and has always been a great factor in world history (Dergachev, 2011; Gudev, 2016). The importance of the "coastal strips" of the Mediterranean seas as a source of "sovereign power" was noted by one of the founders of Russian geopolitics, V.P. Semyonov-Tyan-Shansky (1915). The advantages of the "oceanic economy" were stated by P.N. Savitsky (1997); Fernand Braudel, not without reason, believed that the sea "invariably meant wealth" (1992).

An OECD report estimated the contribution of the ocean economy in 2010 at USD 1.5 trln, or about $2.5 \%$ of global GDP, and employment, at $31 \mathrm{mln}$ jobs. It is assumed that by 2030, the volume of the World Ocean Economy will increase to USD $3 \operatorname{trln}$ (The Ocean ..., 2016). Human activity in the oceans and coastal regions is now expanding on an unprecedented scale, which has been assessed in a number of studies (Böhnke-Henrichs et al., 2013; Stojanovic and Farmer, 2013).

The growing geopolitical and geoeconomic significance of the World Ocean inherent in the first decades of the 21st century is determined, in our opinion, by the following factors: (1) the scale of global trade, combined with global transport and logistics 
hubs confined to maritime areas (about $90 \%$ of international cargo transport occurs by sea links $\left.{ }^{1}\right) ;(2)$ the colossal mineral and raw material potential of the sea shelf, including hydrocarbon resources and the availability of oil and gas production infrastructure (6000 offshore oil and gas platforms operate in the world, providing from 25 to $30 \%$ of global energy consumption), as well as increasing demand for marine biological resources (Druzhinin and Lachininsky, 2019); (3) an increase in the military presence of leading world and regional actors amid growing geopolitical uncertainty and turbulence; (4) concentration of coastal cities as centers of the world economy (out of 55 global alpha cities, 34 are located directly within the coastal zone).

In scientific research, marine resources and the blue economy have been prioritized since the second half of the 20th century (Song et al., 2013; Zhang et al., 2015). Qualitative and quantitative analyses of the blue economy have been carried out in different countries (Fernández-Macho, 2016; Foley et al., 2004; Park and Kildow, 2014). In addition, there has been a significant increase in the number of studies related to analysis of legislation, policies, and strategies related to marine and coastal zones around the world (Clarke, 2006; Fernández-Macho, 2016; Suárez-de Vivero and Rodríguez, 2017; The Ocean ..., 2016). Of particular interest is a number of geopolitical and geostrategic developments related to analysis of the national interests of the world's leading actors in the World Ocean (Gorshkov, 1976; Kildow and McIlgorm, 2010; Kurečić, 2010; Smith, 2011; Stojanovic and Farmer, 2013; Sparke, 2008).

Since the turn of the 1960-1970s, economic and geographical studies of the World Ocean have been actively developed in Russia (by S.S. Salnikov, S.B. Slevich, S.B. Lavrov, V.A. Dergachev, A.P. Alkhimenko, etc.). In the 2010s, their renaissance has been observed, accompanied by a concentration of relevant scientific activity, primarily in the leading coastal cities: Vladivostok (Baklanov, 2018; Baklanov and Moshkov, 2015; Baklanov et al., 2017), Kaliningrad (Fedorov and Kuznetsova, 2019; Fedorov et al., 2017a; Fedorov et al., 2017b), Rostov-on-Don (Druzhinin, 2019a, b, 2020a, b), and St. Petersburg (Lachininskii et al., 2016, 2019; Lachininskii and Semenova, 2015). Its tonality and themes reflect the increasing maritime orientation of modern Russia's socioeconomic space (Druzhinin, 2019b), which is trying (as recorded in the Maritime Doctrine of the Russian Federation) to regain a worthy place among the leading maritime powers. The aim of this article is to accentuate the maritime component of Russia's geoeconomic and geopolitical interests and highlight the scale, degree, and priorities of ensuring Russia's (and its leading eco-

\footnotetext{
${ }^{1}$ https://www.reartek.com/how-to-choose-a-company/. Accessed April 13, 2021.
}

nomic entities) presence in various regions of the World Ocean.

\section{MARITIME ORIENTATION OF MODERN RUSSIA: THE MOST IMPORTANT VECTORS}

The coasts of the Russian Federation are washed by the waters of 3 oceans, 12 seas, and 1 inland sea. Russia in its jurisdiction has $6.2 \mathrm{mln} \mathrm{km}^{2}$ of shelf and continental slope, the area of Russia's exclusive economic zones reaches (according to calculations by (Alkhimenko, 2005)) $7.6 \mathrm{mln} \mathrm{\textrm {km } ^ { 2 }}$ (2\% of the total area of the World Ocean), and the total length of sea boundaries according to estimates (depending on the calculation methods (Kislovsky, 2009; Treivish, 1995) varies from 35300 to $46000 \mathrm{~km}$. Among Russian regions, 23 out of 85 have direct access to seacoasts; they account for a total of $60.1 \%$ of the entire territory of the country and $24.5 \%$ of its population.

Until 1991, Russia's maritime activity was carried out within the framework of a single all-Union economic complex focused on the most active development of the World Ocean (and, accordingly, the country's assertion as not only a continental, but also a sea power (Gorshkov, 1976). After the collapse of the Soviet Union, Russia, having formally become geographically more oceanic (96\% of its maritime boundaries extend to Arctic and Pacific waters (Druzhinin, 2020a)), lost a significant part of the former coastal infrastructure of the Soviet Union (outside the Russian Federation, in the newly independent states, there are 15 large system-forming coastal cities, 9 out of 17 former Soviet shipping companies, and 25 out of 67 of its seaports (Alkhimenko, 2005). The growth of the maritime-oriented post-Soviet Russia that had manifested itself since 1994 was primarily a compensatory, restorative nature. However, by the beginning of the 2000 s, on the whole, the recovery problems were successfully solved, and maritime activity itself became the most important factor in Russia's integration into the global economy and a significant component of Russia's positioning of as one of the most significant (geoeconomically and geopolitically) maritime states of Eurasia.

Russia's maritime orientation manifested itself primarily as a significant expansion of the network of seaports, as well as explosive growth in their cargo turnover (from 1994 through 2020, by 7.8 times, i.e., up to $840 \mathrm{mln}$ t), which was facilitation by Russia's integration into the international division of labor and, accordingly, an increase in mainly raw materials exports (Table 1).

Only during the 2000s were additionally commissioned modern high-tech port complexes introduced, with capacities of $454 \mathrm{mln} \mathrm{t}$, including transshipment 
Table 1. Transshipment volume of most important commodity export cargo by sea in 2016-2018, mln t

\begin{tabular}{l|c|c|c|c}
\hline \multirow{2}{*}{ Main export commodities } & \multicolumn{2}{|c|}{2016} & \multicolumn{2}{c}{2018} \\
\cline { 2 - 5 } & volume, mln t & share of maritime export, \% & volume, mln t & share of maritime export, \% \\
\hline Coal & 166.1 & 82.0 & 199.5 & 80.9 \\
Mineral fertilizers & 31.5 & 51.4 & 34.0 & 52.3 \\
Oil & 254.8 & 89.5 & 260.2 & 98.1 \\
Petroleum products & 156.0 & 90.2 & 150.0 & 96.7 \\
Natural gas & 198.7 & $\ldots$ & 220.6 & $\ldots$ \\
Ore and ferrous metals & 36.9 & 76.4 & 37.3 & 81.5 \\
LNG & 24.2 & 56.2 & 36.7 & 63.2 \\
\hline
\end{tabular}

Source: (Druzhinin and Lachininskii, 2019).

Table 2. Dynamics of transshipment volumes of Russian cargo through seaports of Russia and neighboring countries, mln t

\begin{tabular}{|c|c|c|c|c|}
\hline Types of transshipment/Countries & $2011(2009)$ & 2013 & 2015 & $2016(2017)$ \\
\hline Total cargo & 639.5 & 674.5 & 739.2 & 769.1 \\
\hline Through Russian ports & $535.6(496)$ & 589.8 & 676.8 & $721.9(787)$ \\
\hline Coastal & 32.1 & 36.0 & 56.1 & 71.9 \\
\hline Foreign trade & 503.5 & 553.8 & 620.7 & 650.0 \\
\hline Through ports of neighboring countries & 103.9 & 84.8 & 62.4 & 47.2 \\
\hline Baltic ports & 69.6 & 65.7 & 53.3 & 42.5 \\
\hline Ukrainian ports & 34.2 & 19.1 & 9.1 & 4.7 \\
\hline Total foreign trade cargo of Russia & 607.4 & 638.6 & 683.1 & 697.2 \\
\hline $\begin{array}{l}\text { Share of ports of neighboring countries in transship- } \\
\text { ment volume of foreign trade cargo, } \%\end{array}$ & 17.1 & 13.3 & 9.1 & 6.8 \\
\hline
\end{tabular}

Source: (Druzhinin and Lachininskii, 2019).

of ${ }^{2}$ : hydrocarbons, $286 \mathrm{mln} \mathrm{t}$ (in Sabetta, Varandey, and Novy Port, Murmansk, Ust-Luga, Taman, Tuapse, the port of Olya, etc.); dry cargo ships, $168 \mathrm{mln} \mathrm{t}$, namely: coal (ports of Murmansk, Vysotsk, Taman, Olya, Vostochny, and Vanino), grain (ports of UstLuga, Taman, Olya, Vladivostok, Vanino, Rostov-onDon), and container complexes and universal berths for handling general cargo (ports of Arkhangelsk, St. Petersburg, Ust-Luga, Baltiysk, Taman, Tuapse, Sochi, Olya, Vanino, Sakhalin, Petropavlovsk-Kamchatsky). Overall, there are currently 67 seaports in Russia (with a total capacity of about $1003.6 \mathrm{mln} \mathrm{t} / \mathrm{year}$ with a berthing front length of about 1481000 linear meters ${ }^{3}$ ). The development of port and logistics complexes not only ensured the actual import substitution in this area (Table 2), but also created preconditions for reindustrialization in the main coastal geoeconomic nodes of the country (primarily in St. Petersburg, where, as a result, a developed auto-

\footnotetext{
2 https://www.rosmorport.ru/uploadify/988-f11a995b44861c9c2b1c7e0f502b433e.pdf. Accessed April 13, 2021.

${ }^{3} \mathrm{http}: / /$ morflot.gov.ru/deyatelnost/napravleniya_deyatelnosti/portyi_rf.html. Accessed December 1, 2020.
}

motive cluster formed with a production volume of 372000 cars in 2019).

The construction of a new (absent in the Soviet period) underwater engineering infrastructure, including pipelines, power cables, and fiber-optic Internet lines, has also become a clear embodiment of maritime orientation. Among them, the most ambitious (and financially costly) strategy for construction of undersea gas pipelines has been under implementation since 2000 by Gazprom with the participation of foreign partners (Table 3) for the export of Russian hydrocarbons to the European Union (Germany) and Turkey with a total value of up to USD 29 bln with a pumped volume of $160 \mathrm{bln}^{3}$ (the total volume of natural gas exports by Gazprom to European non-CIS countries in $2019^{4}$ was 199 bln m$^{3}$ ).

Decisions on the construction of offshore gas transmission systems were made, among other things, in the logic of minimizing Russia's dependence on transit countries (taking into account the experience of periodic transit crises with Ukraine and Belarus)

\footnotetext{
${ }^{4}$ http://www.gazprom.ru/about/marketing/europe/. Accessed December 1, 2020.
} 
Table 3. Underwater gas pipelines of Russia

\begin{tabular}{|c|c|c|c|c|c|}
\hline Gas pipeline & Location & $\begin{array}{c}\text { Time period } \\
\text { of implementation } \\
\text { (Start) }\end{array}$ & Project cost & $\begin{array}{l}\text { Length (incl. } \\
\text { underwater) }\end{array}$ & $\begin{array}{l}\text { Pumping } \\
\text { volume }\end{array}$ \\
\hline Blue Stream & $\begin{array}{l}\text { CS Beregovaya (Krasnodar } \\
\text { Krai)-Samsun (Turkey) }\end{array}$ & $2001-2003$ & USD $3.2 \mathrm{bln}$ & $\begin{array}{l}1213 \mathrm{~km} \\
(396 \mathrm{~km})\end{array}$ & $16 \mathrm{bln} \mathrm{m}^{3}$ \\
\hline Nord Stream-1 & $\begin{array}{l}\text { CS Portovaya (Leningrad } \\
\text { Oblast)-Greifswald (Germany) }\end{array}$ & $\begin{array}{c}\text { 2010-2012 } \\
\text { (October 8, 2012) }\end{array}$ & EUR 7.4 bln & $1224 \mathrm{~km}$ & $55 \mathrm{bln} \mathrm{m}^{3}$ \\
\hline Turkish Stream & $\begin{array}{l}\text { CS Russkaya (Krasnodar } \\
\text { Krai)- Kıyıköy (Turkey) }\end{array}$ & $\begin{array}{l}2017-2019 \\
(1.01 .2020)\end{array}$ & USD 6-7 bln & $\begin{array}{l}1090 \mathrm{~km} \\
(910 \mathrm{~km})\end{array}$ & 31.5 bln $\mathrm{m}^{3}$ \\
\hline Nord Stream-2 & $\begin{array}{l}\text { Ust-Luga (Leningrad Oblast)- } \\
\text { Greifswald (Germany) }\end{array}$ & $\begin{array}{c}2019-2021 \\
\mathrm{n} / \mathrm{a}\end{array}$ & EUR $9.5 \mathrm{bln}$ & $1224 \mathrm{~km}$ & $55 \mathrm{bln} \mathrm{m}^{3}$ \\
\hline
\end{tabular}

Source: (Druzhinin and Lachininskii, 2019).

and arresting possible geopolitical risks. However, it was not possible to fully overcome the latter (including due to periodically arising complications in relations with Turkey). At the same time, unfavorable geoeconomic circumstances occurred, and not only marketrelated associated with the volatility of energy prices (including in connection with the coronavirus pandemic), but also long-term, structural ones (competition from LNG, EU energy policy aimed at reducing hydrocarbon imports, US activity on the energy market, etc.). Their presence significantly reduces the overall efficiency of undersea gas transmission facilities, thereby limiting any effort to further expand their capacity.

Over the past quarter of a century, Russia has also implemented numerous projects to construct undersea cable networks, including: the Russian-Japanese Cable Network (RJCN) (Naoetsu (Japan)-Nakhodka (Primorsky Krai), $1800 \mathrm{~km}$ ); HokkaidoSakhalin Cable System (HSCS) (Ishikari (Japan)Nevelsk (Sakhalin Oblast), 570 km); BCS North Phase-2 (Kotka (Finland)-village of Logi (Leningrad Oblast), $280.4 \mathrm{~km}$ ); Caucasian Cable System (Balchik (Bulgaria)-Poti (Georgia)-Sochi (Krasnodar Krai)Novorossiysk (Krasnodar Krai); Kerch Strait Cable (Ilyich (Krasnodar Krai)-Kerch, 46 km), etc. Until recent years, a particular problem was associated with the lack of entry points to the global Internet infrastructure in Russia's Arctic zone. A unique project by Megafon and the Finnish infrastructure operator Cinia, to be implemented from 2020 to 2023, is designed to eliminate this serious constraint and will be the shortest data transfer route from Europe to Asia. $^{5}$

In modern Russia, the maritime factor is also used in organizing international (and interregional) power flows. In the early 2000 completed a large energy project between the EU and the Russian Federation Baltic

\footnotetext{
${ }^{5}$ http://www.vedomosti.ru/technology/articles/2020/07/19/ 834927-megafon-nachal-stroit. Accessed January 24, 2021.
}

Energy Ring. Electricity from the Leningrad NPP went along two cable branches from the village of Kernovo, located near Sosnovy Bor in Leningrad Oblast, to the town of Mussalo, located near the Finnish city of Kotka. The length of the undersea cable is approximately $150 \mathrm{~km}$. The high-voltage undersea cable annually transmits electrical energy in the amount of $8.7 \mathrm{bln} \mathrm{kWh}$. A significant underwater infrastructure project was built in 2015-2016: an energy bridge across the Kerch Strait (with a capacity of up to 810 MW), which connects the power systems of Crimea to UES of Russia.

A factor of Russia's maritime orientation is also its global energy and raw materials specialization (according to the Federal Customs Service almost $65 \%$ of Russian exports are currently fuel and energy products), contributing towards the interests of Gazprom and other specialized large business structures (Lukoil, NOVATEK, Rosneft, etc.) in oil and gas fields in Russia's coastal and shelf zones. Since 1995, Lukoil has been exploring and developing hydrocarbon deposits in the northern Caspian Sea. Since 1999, the production of energy resources has also been carried out (since 2007 under the control of Gazprom) on the shelf of Sakhalin Island (in 2006 construction of Russia's first LNG plant began; in October 2018, its share amounted to $4.8 \%$ of the total LNG demand for APR and about $3.6 \%$ of global LNG demand ${ }^{6}$ ). Offshore gas production centers are being formed by Gazprom in Kamchatka Krai, as well as in the shelf zones of the Sea of Okhotsk and Kara Sea; the same company started oil production at the Prirazlomnoe field in the Pechora Sea and is also working on a project for an LNG plant in Vladivostok. Rosneft, which currently owns 55 licenses for areas in waters of Russia's Arctic, Far Eastern and southern seas, is also showing active interest also in the sea. A large maritime oriented (based on LNG technologies) project is being

\footnotetext{
${ }^{6}$ Annual report of PJSC Gazprom for 2018. Moscow, 2019. https://www.gazprom.ru/f/posts/01/851439/gazprom-annualreport-2018-ru.pdf. Accessed July 10, 2019.
} 
implemented on the northern Yamal Peninsula by NOVATEK (in startup 2018, it produced $68.8 \mathrm{bln} \mathrm{m}^{3}$ of natural gas for subsequent liquefaction), which is also starting to create support bases for its business (LNG storage and transshipment terminals in Sabetta), as well as in Murmansk Oblast and Kamchatka. It is highly probable that in the next five years in the Russia's Arctic zone, Rosneft, which in November 2020 announced commencement of the ambitious Vostok Oil project, is forming another significant coastal energy production center on the Taimyr coast, which will connect the currently planned (potentially the largest in this macroregion) seaport of Bukhta Sever (it is expected to be commissioned in 2024; the oil transshipment capacity here in the future should reach $115 \mathrm{mln} \mathrm{t}^{7}$ ), about 2000 trunk pipelines, as well as West Irkinskoe and other oil fields, oriented towards maritime logistics and predominantly foreign markets.

In recent years, there has been a positive trend in the Russian fishing industry, localized primarily in Russian Pacific waters (38\% of all catches are in Kamchatka and 22\% in Sakhalin). In particular, the total catch of fish and seafood in the Russian Federation increased from $3.2 \mathrm{mln} \mathrm{t}$ in $2002^{8}$ to $5.4 \mathrm{mln} \mathrm{t}$ in $2019^{9}$ ), including orientation towards the markets of neighboring states (China, Japan, etc.).

The multidimensional growth of maritime activity corresponds to the positive dynamics of the Russian shipbuilding industry, combining more than 150 enterprises, located primarily in large coastal urban agglomerations: St. Petersburg (JSC Admiralty Shipyards, OJSC Baltic Shipyard, and other leading Russian shipbuilding industries), Vladivostok (JSC Zvezda and another 58 enterprises and firms specializing in ship repair and shipbuilding), Rostov-on-Don (24 medium and small enterprises), Kaliningrad (JSC Yantar, etc.), Arkhangelsk (JSC PO Sevmash, etc.). Since 2007, two nuclear-powered icebreakers-50 Let Pobedy (2007) and Arktika (2020) - have been commissioned, as well as 5 diesel-powered icebreakers and Russia's first Afromax-class tanker, the Vladimir Monomakh (2020). A system of administrative and investment-financial measures is being introduced, aimed at coordinating (in the format of the United Shipbuilding Corporation established in 2007, as well as the Marine Instrumentation Corporation established in April 2020) and supporting national shipbuilders. The most important positive shift in the development of domestic shipbuilding was the production breakthrough in constructing not only large, including nuclear-powered icebreakers, but also spe-

\footnotetext{
${ }^{7}$ Rosneft has launched a new Vostok Oil project in Taimyr. Electronic edition. http://www.interfax.ru/business/708350. Accessed December 12, 2020.

${ }^{8} \mathrm{http}: / /$ nationalatlas.rf/cd2/392/392.html. Accessed October 15, 2020.

${ }^{9} \mathrm{http}: / /$ marketing.rbc.ru/articles/11545/. Accessed October 15, 2020.
}

cialized ice-class vessels of the leading national operators in the Arctic zone (including the fleet of Norilsk Nickel, Rosneft, NOVATEK, etc.), as well as numerous vessels serving the export of oil and LNG.

The recovery of Russian shipbuilding is also favored by the State Arms Development Program since 2011, which also includes modernization of the navy. During this period, 100 surface and submarine combat vessels were commissioned, including: 8 strategic nuclear submarines of project 955 Borey (their total number increased to 10), 20 nonstrategic submarines, 35 corvettes, 15 frigates, 6 large landing ships of project 11711 Yantar, etc. (due to the technological and financial problems that arose, this program, however, was not realized in full). As a result, according to the situation in 2019, the Russian Navy had 213 ships, including 69 submarines (of which 46 are nuclearpowered); the Russian Navy numbered 150000 people. ${ }^{10}$

As a result, maritime activity in post-Soviet Russia not only received a multidimensional impulse, but also acquired new additional vectors, facets. This, in turn, initiated a partial return of the country to the cohort of the leading maritime powers, creating prerequisites for expanding the area of its presence in the World Ocean.

\section{RUSSIA'S MULTIVECTOR PRESENCE IN THE WORLD OCEAN}

Russia's presence in the World Ocean (motivated by its national interests formulated in the Maritime Doctrine of the Russian Federation) is ${ }^{11}$ polysubjective, multidimensional, and nonequilibrium for certain specific marine (and oceanic) waters. In this virtually multivector maritime activity, the interests of the Russian state (including military-strategic ones) are combined with an orientation towards effective use of the maritime factor by the largest Russian companies (among the first 100 Russian companies according to the rating of RBK-500, 42 are maritime-oriented; their total share in the total output of goods and services in the Russian Federation reaches 16.5\% (Druzhinin, 2019a), as well as oriented towards the everyday life of broad strata of the population: more than $21 \mathrm{mln}$ people live immediately in coastal cities and municipal districts, i.e., $14.4 \%$ of the country's population; up to $22.5 \mathrm{mln}$ annually travel to the most popular Russian seaside resorts (up to $15 \mathrm{mln}$ in Krasnodar Krai and $7.5 \mathrm{mln}$ in Crimea); according to precoronavirus 2019 information, about $14 \mathrm{mln}$ more visited countries with prevailing seaside recreation

\footnotetext{
${ }^{10} \mathrm{http}: / /$ structure.mil.ru/structure/forces/navy/news.htm?blk= 10339759\&id=8570@egClassification\&objIn-

Block=2520\&ra=egNews. Accessed December 1, 2020.

${ }^{11}$ Maritime doctrine of the Russian Federation. http://static.kremlin.ru/media/events/files/ru/uAFi5nvux2twaqjftS5yrIZUVTJan77L.pdf. Accessed December 1, 2020.
} 
(including $7 \mathrm{mln}$ to Turkey, $1.2 \mathrm{mln}$ to Thailand, $1 \mathrm{mln}$ to the UAE, etc.). ${ }^{12}$

Russia's maritime multivector nature is unstable and asymmetric. It is, of course, limited by geoeconomics (up to $92-93 \%$ of the country's total foreign trade turnover is carried out directly with states of the Eurasian continent); it is predetermined by geopolitics (imperatives to contain competitors in their own maritime instability); however, it is associated to an even greater extent with the aquatic-territorial architecture of Russia itself, primarily with the historically formed actual diversity of its exits to a particular sea basin.

A century ago, comprehending the country's maritime problems, one of the founders of classical Eurasianism, P.N. Savitsky, figuratively noted that Russia's coast is, as it were, quartered, i.e., it is torn into four sections, isolated in the economic and naval sense (Tridtsatye gody ..., 1931). Modern Russia's nonequilibrium facades already faces five sea areas encircling it (including the Caspian), each of which is significant, with unconditional natural, economic, and residential specifics.

The most significant (for export and especially import) loading terminals are concentrated of the $\mathrm{Bal}$ tic, providing about $30 \%$ of cargo turnover of all Russian seaports; there are also two (out of four) main underwater gas pipelines and a number of existing coastal industrial clusters (auto assembly, food industry, chemistry, shipbuilding). Russia's actual sea capital, St. Petersburg, is located here, with its powerful scientific, educational, production, technical, innovative, and technological potential with a maritime focus (concentrated, in particular, at the Kuznetsov Naval Academy, St. Petersburg State Marine Technical University, Admiral Makarov State University of Maritime and Inland Shipping, Central Marine Research and Design Institute, etc.).

The Black Sea coastal direction also provides almost a third of cargo turnover of Russian seaports (specializing in the export of oil and oil products, as well as grain); the Blue Stream and Turkish Stream pipeline systems are also located here, as well as the main coastal resort areas (the Black Sea coast of the Caucasus and Crimea). In addition to the Baltic Sea facade, this is the most important corridor of the country (in total, the Black and Baltic seas provide more than $60 \%$ of total cargo turnover of Russian seaports) and a priority residential space attractive for migrants (up to $43 \%$ of the total Russian population of coastal cities live in the Baltic; in the Azov-Black Sea basin, almost 26\%).

The situation in the Russia's Arctic and Pacific zones stands in stark contrast to the western and southwestern sea borders; here, predominantly central

\footnotetext{
${ }^{12}$ Statistics on departure of Russians abroad in 2019. [Electronic resource] http://www.atorus.ru/news/press-centre/new/ 50475.html. Accessed January 27, 2020.
}

economic and residential development of the coast is combined with the presence of the most important fishing and oil-and-gas water areas.

Pacific Russia is responsible for almost $66 \%$ of allRussian catches and other biological resources and almost $25 \%$ all Russian cargo turnover of seaports (this indicator is growing at a faster rate); large exportoriented energy projects are being implemented on the Sakhalin shelf.

The Arctic vector is distinguished by the militarypower component (up to $30 \%$ of the Russian Navy's fleet), fishery clusters (about $20 \%$ of the national fishing industry), and powerful mineral resource base of shelf zone resources and emerging oil and gas complexes on the Yamal Peninsula and Eastern Siberia. Its axial element has been the Northern Sea Route for almost nine decades (transport of goods along this route in 1990 amounted to $7 \mathrm{mln} \mathrm{t}$; by 2000 it decreased to 1.5 , again reaching the Soviet volume in 2016, and in 2020 exceeding $32 \mathrm{mln} \mathrm{t}$ ), demonstrating its ever-increasing demand under the influence of climatic and geopolitical changes, as well as expanding development of the Arctic's resource potential (Vardomsky, 2019; Pilyasov and Putilova, 2020).

In the reformatting of Eurasia and reintegration processes taking place in the post-Soviet space, the Caspian vector of maritime activity has retained its significance for Russia, with its existing oil and gas production (the Korchagin, Filanovsky, etc., fields), its so far only partially used port infrastructure, and rather large coastal urban agglomerations (including Makhachkala, Russia's leading city in population growth dynamics).

The presence of long seacoasts and adjacent water areas in Russia, falling either under the direct jurisdiction of the country or to the area of its priority economic and military-strategic interests, predetermine the greatest saturation of Russia's maritime activity precisely in the near (for Russia) zone of the World Ocean. The gradual shift of global economic activity (and, accordingly, Russian foreign trade interests) observed in recent years towards the coastal zones of East, Southeast, and South Asia, as well as (Fardella and Prodi, 2018) the renewed increasing geoeconomic importance of the Mediterranean, increases the value of Russia's presence in the entire Circumeurasian zone, including the Indo-Pacific Basin, where the possibilities of realizing Russia's tested maritime strategic goals are determined by the sharply intensified (since 2013) confrontation between China and the United States.

American interest in the Indian and Pacific oceans is based on the work of a think tank (Project for the Next American Century), teaming up such experts as R. Kagan, V. Kristall, F. Fukuyama, P. Wolfowitz, etc., who seek to substantiate preservation of US global dominance in the 21st century. According to their forecasts, the global center of power will shift to 
the Indo-Pacific region, and competition for influence and resources in this region may escalate into an armed conflict. In particular, T.P.M. Barnett (cited from (Murphy, 2010)) justifies US attention to the Indian Ocean by the fact that it is the most nuclear of oceans, where ships of all nuclear powers are present, including Great Britain, France, China, Russia, India, Pakistan, and Israel.

For China, the geoeconomic importance of the Indian Ocean is determined primarily by the fact that more than $80 \%$ of the oil imported by the country passes through it. It is no coincidence that China's Maritime Strategy (Payette and Guorui, 2017) indicates that the most important motive for development of sea power is a sharp increase in foreign trade via sea links. In 2013, China adopted the 21st Century Maritime Silk Road as a development strategy aimed at expanding infrastructure connectivity in Southeast Asia, Oceania, the Indian Ocean, and East Africa.

The 2015 White Paper of the PRC Government emphasizes the need to move from protection of exclusively coastal areas to comprehensive security both in coastal areas and on the high seas. China's modern military strategy distinguishes the maritime direction of development of the armed forces as one of four key ones (along with outer space, cyberspace, and the nuclear sphere). According to the International Institute for Strategic Studies, in 2018, China possessed 62 submarines, equal in number to the Russian submarine fleet and second only to the American fleet (68 submarines) ${ }^{13}$. India, which has more than 180 ships and 200 naval aviation aircraft, is actively increasing its naval potential (Druzhinin and Lachininskii, 2019).

For Russia, in this context, it is strategically important not only to display the flag in the southern and eastern maritime borders of Eurasia, but also to partner with the leading regional centers of power within the framework of their maritime (primarily transport and logistics) projects.

In 1999, a number of transport companies from India, Iran, and Russia signed an agreement on export-import transport of containers along the Sri Lanka-India-Iran-Caspian Sea-Russia international transport corridor (ITC). In 2000, during the second Eurasian conference on transport, an intergovernmental agreement was signed on the creation of a North-South ITC. The participating countries were Russia, Iran, and India. The final destinations of the North-South ITC on Russian territory should be the ports of St. Petersburg and Ust-Luga, from where cargoes from the Persian Gulf states, India, and Southeast Asian countries can be sent to Northern European countries. Thus, the water area of the Arabian Sea and

\footnotetext{
${ }^{13} \mathrm{http}: / /$ tass.ru/mezhdunarodnaya-panorama/6367033. Accessed December 1, 2020.
}

Persian Gulf also falls into the sphere of presence desirable for the Russian Federation.

Demonstrating Russia's multivector, maritime policy in the World Ocean is focused, as a result, on the following geographical directions: the Atlantic, Arctic, Pacific, Caspian, Indian Ocean and Antarctic (Table 4).

Russia's sphere of maritime activity, as a result, acquires an almost universal scale; the number of key (for Russia) regions of the World Ocean is also increasing (the phrase key region is symptomatically widely used in the Strategy for the Development of Maritime Activity of the Russian Federation until 2030, which entered into force in $2019^{14}$ ). Nevertheless, Russia's full-scale presence as a leading maritime power on the world stage is constrained by a number of significant factors, which have fully manifested themselves, including in the last six to seven years, amid growing geopolitical turbulence and geoeconomic competition.

\section{CONSTRAINTS AND LIMITATIONS OF MARITIME ACTIVITY IN MODERN RUSSIA}

The constraints and limitations of the Russian Federation's maritime activity are diverse, differing in their origin, strength, and range, as well as the time horizon of action. The most prolonged, although subject to partial modification (including due to observed climate changes (Smith, 2011)), generating, in particular, more favorable opportunities for maritime logistics in the Arctic) are the natural and climatic conditions of the maritime areas that delimit the country, requiring additional costs for infrastructure support of navigation, ice support of ships, which significantly increases the cost of major construction and labor resources.

The constraint on Russia's maritime activity is also the historically formed spatial asymmetry between the main multifunctional coastal centers that solve production, logistics, educational, and other maritime problems on a national scale (St. Petersburg, Kaliningrad), or its large macroregions (Murmansk, Arkhangelsk, Vladivostok) and the remote, most important raw material (energy and biological resources) water areas of the Russian Arctic and Far East.

In the post-Soviet period, the country acutely felt the technical and technological restrictions on maritime activity, including in relation to the aging fleet of civil and military ships and rather slow pace of its modernization. Based on the situation for 2019, among the 2717 vessels of the Russian merchant and fishing fleet, 1783 were built 25 or more years ago, while only 212 were less than 5 years old. Despite the positive

\footnotetext{
${ }^{14}$ Strategy for the Development of Maritime Activity of the Russian Federation until 2030. Order of the Government of the Russian Federation of August 30, 2019 no. 1930-r.
} 
Table 4. Priority areas of Russia's presence in the World Ocean

\begin{tabular}{|c|c|c|}
\hline $\begin{array}{c}\text { Geographic } \\
\text { direction }\end{array}$ & Region & Geoeconomic and geopolitical interests \\
\hline \multirow[t]{3}{*}{ Atlantic } & Baltic Sea & $\begin{array}{l}\text { Development of coastal port infrastructure; construction of logistics and hydrocarbon pro- } \\
\text { cessing complexes; overcoming exclave of Kaliningrad Oblast }\end{array}$ \\
\hline & $\begin{array}{l}\text { Black Sea } \\
\text { Sea of Azov }\end{array}$ & $\begin{array}{l}\text { Ensuring balance of geopolitical forces, effective integration of Crimea into Russia's socio- } \\
\text { economic system, development of gas transport system; expansion of capacity of port com- } \\
\text { plexes in line with growth of energy exports; implementation of transport and transit } \\
\text { potential of coastal territories, development of coastal resorts }\end{array}$ \\
\hline & $\begin{array}{l}\text { Mediterra- } \\
\text { nean Sea }\end{array}$ & $\begin{array}{l}\text { Ensuring stability of commodity flows from Russia to countries of region (traditional and } \\
\text { new Russian export markets); military strategic deterrence }\end{array}$ \\
\hline \multicolumn{2}{|l|}{ Arctic } & $\begin{array}{l}\text { Ensuring unconditional sovereignty of Russian Federation over waters and territories of Arc- } \\
\text { tic under its jurisdiction, development of Northern Sea Route; development of Arctic conti- } \\
\text { nental shelf and building up of processing plant infrastructure on coast. Creation and } \\
\text { implementation of adaptive (taking into account specifics of North) technologies for marine } \\
\text { economic activity. Development of unique icebreaker fleet and its own corporate fleet of } \\
\text { operators for development of Arctic zone. }\end{array}$ \\
\hline Pacific & $\begin{array}{l}\text { Sea of Japan } \\
\text { Sea of } \\
\text { Okhotsk } \\
\text { Bering Sea }\end{array}$ & $\begin{array}{l}\text { Development of seaports in interests of building up capabilities of geoeconomic corridor in } \\
\text { Russian East and Russia's inclusion in Eurasian infrastructure projects. Ensuring economic } \\
\text { and infrastructural connectivity of Russia's Far Eastern regions; formation of reliable } \\
\text { resource base for gas supply and organization of future export supplies, including LNG; } \\
\text { development of full cycle of fish and seafood processing. Ensuring military-strategic security } \\
\text { of Russia's eastern border }\end{array}$ \\
\hline \multicolumn{2}{|l|}{ Caspian } & $\begin{array}{l}\text { Development and modernization of seaports; formation of modern oil and gas production } \\
\text { complex in Russian sector of Caspian; solving regional security problems }\end{array}$ \\
\hline \multicolumn{2}{|c|}{ Indian Ocean } & Expansion of Russian shipping; sales of Russian shipbuilding products \\
\hline \multicolumn{2}{|l|}{ Antarctic } & $\begin{array}{l}\text { Use of aquatic biological resources; scientific research of hydrosphere, atmosphere, and } \\
\text { cryosphere }\end{array}$ \\
\hline
\end{tabular}

Source: (Druzhinin and Lachininskii, 2019).

dynamics in Russian civil shipbuilding (in 2013, 85 ships were commissioned, 42 in 2015, 55 in 2017, and 95 in 2019), ${ }^{15}$ these volumes are still insufficient for either radical modernization of the country's maritime fleet on its own production and technological base or for the effective functioning of domestic shipbuilding enterprises (their average load does not yet exceed $40-50 \%$ ).

In a certain sense, Russia's diversified maritime activity is constrained by structural restrictions, also manifested in recent decades and associated with imbalances between the volume of military (where Russia provides $12 \%$ of the global volume, ranking

\footnotetext{
${ }^{15}$ https://minpromtorg.gov.ru/common/upload/files/docs/Minpromtorg-2020.pdf. Accessed April 13, 2021.
}

second after the United States) and civil shipbuilding (the military sector is responsible for about $70 \%$ of orders, including $21 \%$ for export, while civilian output makes up about $30 \%$ of the nomenclature, and exports make up less than $2 \%^{16}$ ), as well as between the scale of export-import operations yielded by maritime logistics and the capabilities of the Russian merchant fleet itself (the Russian Federation is responsible for about $3.6 \%$ of the total cargo turnover of seaports of the world, but only $1.2 \%$ of the tonnage of the world merchant fleet, which places Russia 19th in the world for this indicator; only a third of ships owned by Russian

\footnotetext{
${ }^{16}$ http://rg.ru/2016/06/09/sudostroenie-odin-iz-glavnyh-placdarmov-podema-ekonomiki-rossii.html. Accessed October 15, 2020.
} 
business entities are registered under the Russian flag). ${ }^{17}$

A priority factor, highly actualized in the last two decades and significantly influencing practically all spheres of Russia's maritime activity, is internationalization, understood as a high degree of dependence on foreign markets, technologies, investments. A particular, but characteristic example is, in this case, Primorsky Krai, where about $85-90 \%$ of fish and seafood catches are exported annually, primarily to China and the South Korea (Rybokhozyaistvennyi ..., 2018). With an eye on foreign markets, such large-scale, flagship projects for the Russian maritime economy as Turkish Stream, Nord Stream-2, Yamal-LNG, and Vostok-Oil are being implemented, which puts Russia's maritime activity in direct dependence not only on the dynamics of the global economy, but also on the geopolitical situation, including the nature of interaction between Russia and its main foreign counterparts (states, interstate institutions, and major corporations in sectors relevant to the Russian economy).

In this regard, a significant limitation was also the policy currently implemented by the United States and EU countries (in the United States, SSI-Sectoral Sanctions Identifications) and sectoral and secondary sanctions with respect to key economic agents of Russia involved in the development of hydrocarbon resources on the Arctic shelf, as well as companies of the Russian military-industrial complex and transport operators. This policy was extended, among other things, to leading subjects of maritime activity of the Russian Federation, including Rosneft (sectoral sanctions), Gazprom Neft (sectoral sanctions), Transneft (sectoral sanctions), Lukoil (sectoral sanctions), etc.

The most significant sanctions regime is for maritime oriented economic entities of the Republic of Crimea and the federal city of Sevastopol (actually deprived of the opportunity to carry out foreign economic activity directly), in particular: Chernomorneftegaz (nonsectoral sanctions), Sevastopol Commercial Port (nonsectoral sanctions), Kerch Commercial Port (nonsectoral sanctions), Kerch Strait Ferry Line (nonsectoral sanctions), More Shipyard (nonsectoral sanctions), Zaliv Shipyard, etc.

An opportunistic factor, but, nevertheless, one limiting Russia's maritime activity was the COVID-19 pandemic, which triggered another (very deep) world economic (including consumer, investment, trade) crisis. Its manifestations in Russia will undoubtedly affect the port economy (both in 2008 and 2014, the decline in prices for basic Russian raw materials was accompanied by an increase in their exports in physical terms; now the situation is different: for the first time since 1999, cargo handling in Russian ports began to decline, decreasing in 2020 by $3 \%$ versus the

\footnotetext{
${ }^{17}$ UNCTAD (2019). Review of Maritime Transport 2018 (United Nations publication. Sales No. E.18.II.D.5 New York and Geneva).
}

same period the previous year ${ }^{18}$ ), as well as oil and gas projects in shelf zones and, of course, due to the inevitable general curtailment of investment demand by corporations and government orders for shipbuilding. Thus, a significant limiting factor for Russia's marine economy is the rather limited current (and for the medium term) possibilities of state financial and investment support. Much-needed effective coordination between the main subjects of Russia's maritime economy (large national companies) and the positive externalities of their industrial and infrastructure projects are insufficient (for the development of maritime oriented segments of mechanical engineering, for the sustainable progressive socioeconomic dynamics of coastal territories developed by big business).

All these circumstances significantly limit the possibilities of Russia's presence in the World Ocean, transforming development of the country's maritime activity not only into an indisputable geopolitical and geoeconomic imperative, but also a multidimensional strategic problem that requires systemic solutions, integrative approaches and, without a doubt, resources and political will.

\section{MAIN PRIORITIES AND DIRECTIONS FOR BUILDING UP AN EFFECTIVE RUSSIAN PRESENCE IN THE WORLD OCEAN}

The Soviet Union's maritime interests were global. For almost the entire post-Soviet period, Russia has consistently sought to increase its maritime economic activity, recover (at least partially) its former naval potential, and thereby strengthen and expand its presence not only in the maritime areas delimiting the country, but also in the World Ocean as a whole.

Since 1992 (when the program Revival of the Russian Merchant Fleet for 1993-2000 came into force), the maritime vector of development of the Russian Federation is symptomatically recorded in numerous state doctrines and federal programs specially developed and approved by the country's leadership: The Federal Target Program (FTP) World Ocean (1998), Marine Doctrine of Russia for the Period up to 2020 (2001), FTP Creation of a System for Basing the Black Sea Fleet on the Territory of the Russian Federation in 2005-2020 (2004), FTP Development of Civil Marine Technology for 2009-2016 (2008), Strategy for Development of Maritime Activity of the Russian Federation (2010; amended, 2019), Strategy for Development of Seaport Infrastructure in Russia until 2030 (2012), Maritime Doctrine of the Russian Federation (2015), etc. The approaches formulated in these documents are becoming increasingly complex from year to year; recently, they have very clearly empha-

\footnotetext{
${ }^{18}$ Freight turnover of seaports for 10 months of 2020 [Electronic edition]. https://www.morport.com/rus/news/gruzooborotmorskih-portov-rossii-za-10-mesyacev-2020-goda. Accessed December 3, 2020.
} 
sized Arctic and Far Eastern themes, and have particularly focused on the military-power, technical and technological, infrastructural, scientific, and economic priorities of the country's maritime activity. ${ }^{19}$ The current situation in the modern world (the effects of deglobalization and economic protectionism, risks of socioeconomic stagnation, escalation of geopolitical confrontation) initiates, nevertheless, an even more consistent linking of Russia's maritime efforts with its modern economic interests and capabilities, modernizing the issues of the effectiveness of Russia's presence and its commercial and military structures (Matishov et al., 2007) in the World Ocean.

The effectiveness, in this case, is primarily associated with ensuring balance (proportionality of dynamics, mutually supportive development) of various components of the country's maritime activity: its commercial and military components and resourceextracting structures and providing their investment demand, isolated marine macroregions (Baltic, Black Sea region, etc.), actual maritime industries and the economy of coastal regions localizing them, etc.

Further development requires, in this regard, first of all, system of naval support of Russia's geoeconomic interests and its leading corporations, whose activity are increasingly becoming transnational, transcontinental in nature.

The Middle East vector of Russian companies is primarily related to their activity in Egypt, Iraq, and Syria. In October 2017, Rosneft closed a deal to acquire a $30 \%$ stake in a concession agreement for the development of the Zohr gas field in Egypt. ${ }^{20}$ Also in Egypt, since 1998, Lukoil has been involved in the joint production project WEEM (West Esh El-Mallaha) near the city of Hurghada. ${ }^{21}$ The resources of the African continent are also in the sphere of interests of Russian companies. In June 2014, Lukoil entered a deep-water project on the Etinde block on the shelf of the Gulf of Guinea, owned by Cameroon (the entry deal was concluded in March 2015). ${ }^{22}$ In Southeast Asia, Rosneft is participating in a joint project to construct an oil refining and petrochemical complex in the city of Tuban (East Java, Indonesia). ${ }^{23}$ The intensification of Russian-Venezuelan trade and economic relations led to the fact that in 2017 the Venezuelan authorities issued licenses to Rosneft to develop the

\footnotetext{
${ }^{19}$ Strategy for Development of Maritime Activity of the Russian Federation until 2030. Order of the Government of the Russian Federation of August 30, 2019, no. 1930-r.

${ }^{20} \mathrm{http}$ ://www.rosneft.ru/business/Upstream/ProductionAndDevelopment/Proekt_Zohr_Egipet/. Accessed December 1, 2020.

${ }^{21}$ http://lukoil.ru/Business/Upstream/Overseas. Accessed December 1, 2020.

${ }^{22} \mathrm{http}$ ://lukoil.ru/Company/BusinessOperation/GeographicReach/Africa/LUKOILinCameroon. Accessed December 1,

${ }^{23}$ http://www.rosneft.ru/press/releases/item/188837/. Accessed December 1, 2020.
}

Mejillones and Patao offshore fields for a period of 30 years (the company is the development operator of the field and will be able to export the entire output volume, including LNG) ${ }^{24}$ Since July 2017, Lukoil has been involved in developing a number of oil fields on the shelf of the Gulf of Mexico (Mexico). ${ }^{25}$ These areas of Russian geoeconomic interests are already symptomatically combined with bases deployed by the Russian Navy (in Syria, Vietnam) as well as with foreign seaports open to access by Russian warships. There are eight in the Mediterranean Sea, four in the Arabian Sea, one in the Caribbean (Venezuela), one in the Tasman Sea (Australia), and one in the Gulf of Guinea (Cameroon). Russia's buildup of a grouping of modern military vessels equipped with hypersonic weapons, as well as further expansion of the network of possible basing points, will make it possible not only to show the flag, ${ }^{26}$ but also to yield potential for force support so necessary for the country, its economy, and expansion of its presence in foreign markets.

The transition from the currently prevailing "basin" practice (and logic) of the maritime economy to the formation of a Unified System of Maritime Activity of Russia, which envisages not only the development of transoceanic transport and logistics ties (based primarily on the infrastructure of the Northern Sea Route, as well as on the system of inland navigable waterways, including the White Sea-Baltic, VolgaBaltic, Volga-Don, and other canals), but also the building of flexible interbasin interactions (at the corporate and national levels), when, e.g., in case of emergency, commodity flows of the Black Sea region can be diverted to the Baltic and from the Caspian to Murmansk, Arkhangelsk, and vice versa) (Druzhinin, 2020b).

In the modern global context, characterized by experts as the dominant period of the next disintegration cycle (Shuper, 2016), it becomes extremely necessary to achieve the maximum possible self-sufficiency of the country's maritime economy (within the framework of Russia's economic system and its partnerships in the Eurasian Economic Union), implemented both on the basis of targeted protectionist measures (primarily in the interests of Russian shipbuilding and mechanical engineering in general), and in formats of theory and practice that have successfully proven themselves in the Soviet period in forming the aquatic-territorial complex. It is necessary to cultivate and maintain the so far sparse (but nevertheless

\footnotetext{
${ }^{24}$ http://www.rbc.ru/business/17/12/2017/

5a35abe89a7947eca62f30bb. Accessed December 1, 2020.

${ }^{25}$ http://www.vedomosti.ru/business/articles/2020/01/23/ 821347-lukoil. Accessed December 1, 2020.

${ }^{26}$ In November 2020, it became known that the Government of Iran is ready to provide Russia and China with all the conditions for a military presence in the ports of Chabahar, Bandar Abbas, and Bushehr in accordance with the military element of the agreements.
} 
already developed, including in the Arctic (Pilyasov and Putilova, 2020), practices of joint construction and use by corporations (primarily with state participation) of infrastructure in coastal zones, as well as purposefully increase the fiscal and overall socioeconomic return from maritime economic activity (ensured by both its diversification and the shift of priorities in the subcontracted policy of major maritime oriented Russian companies in favor of Russian machinery industry enterprises).

The need to cultivate and implement systemic approaches both towards the use of natural resources within particular seas (the economic exploitation of which, devoid of an orientation towards an integrated result, contradicts, among other things, the natural systemic nature of shelf waters (Matishov et al., 2007), and in general the administration of economic, residential, and ecological processes within the framework of aquatic-territorial structures) requires the priority development of marine administration in the country. Its formats and contours have recently been actively discussed (Baklanov et al., 2017), including the possible creation of a specialized government body (a special Maritime Ministry (Matishov et al., 2007), or certain maritime activity councils of the federal and regional basin (Voitolovsky, 2005)).

\section{CONCLUSIONS}

In the last two decades, Russia, which is increasingly more actively involved in transnational economic interdependencies and is trying to achieve a multivector nature in its foreign policy, is turning towards the World Ocean. This is primarily manifested in its increasing maritime economic activity (the development of seaports and industrial port complexes, coastal and shelf energy projects, revival of domestic shipbuilding industries, construction of underwater gas transport systems, etc.), in strengthening Russia's geostrategic (including military force) presence of the Russian Federation both in the adjacent and in more remote water areas of the World Ocean. These processes more clearly highlight and delimit sea (oceanic) spaces (primarily bordering) as a sphere of priority geoeconomic and geopolitical interests of our country.

It seems that the most important geopolitical and geoeconomic target for positioning Russia in the World Ocean by the middle of the 21st century should be overcoming what a century ago the geographer and economist P.N. Savitsky (1997) defined as: Transport deprivation of landlocked Russia (in the sense of its active participation in world economic exchange). At present, such deprivation has already been partially eliminated, but, at the same time, the problem of building up and full-scale use of the maritime transport and logistics potential of the Russian Federation (including in the development of the resource potential of the Arctic, as well as the regions of the Russian
Far East), as well as the formation and entry of national value chains into promising markets. In strategic terms, it is equally important to achieve sustainable and effective (for Russia as a whole and its coastal regions) maritime activity in the waters delimiting the country (including their shelf zones) and, on this basis, not only to strengthen Russia's geopolitical presence in them, but also to ensure positive socioeconomic and residential dynamics practically along the entire perimeter of the Russian sea (oceanic) coast. For the sake of solving these long-term, fundamental problems, Russia will need to find, mobilize, and increase not only the appropriate investment, financial, scientific, and technological, human, and other resources, but also to efficiently coordinate the participants in maritime economic activity and find an acceptable (mutually supportive) balance of military and commercial maritime activity. It is just as important-while maintaining the trend of internationalization of Russia's priority maritime industries that has developed over the past three post-Soviet decades, imparting Russia with a real multivector nature-to acquire the greatest maritime self-sufficiency and the ability, to the necessary and fullest extent, to nationalize (in the interests of all of society, not individual economic spheres and corporations!) Russia's positive image of its positioning as a leading maritime power.

\section{FUNDING}

The study was supported by a grant from the Russian Science Foundation (project no. 19-18-00005), as well as within the state-ordered research theme of IG RAS (no. 0148-2019-0008, "Problems and Prospects of Russia's Territorial Development under Conditions of Its Unevenness and Global Instability").

\section{CONFLICT OF INTEREST}

The authors declare no conflict of interest.

\section{REFERENCES}

Alkhimenko, A.P., Russian marine industry: development trends and problems, in Morekhozyaistvennyi kompleks Rossii (Russian Marine Industry), St. Petersburg: Ross. Geogr. O-vo, 2005, pp. 5-23.

Baklanov, P.Ya., Marine spatial planning: theoretical aspects, Balt. Reg., 2018, vol. 10, no. 2, pp. 76-85.

Baklanov, P.Ya. and Moshkov, A.V., Spatial differentiation of the structure of the regional economy of the Russian Arctic zone, Ekon. Reg., 2015, no. 1 (41), pp. 53-63.

Baklanov, P.Ya., Ermoshin, V.V., Karakin, V.P., Zharikov, V.V., Nguyen Van Cu, and Dao Dinh Cham, Coastal-marine nature management in Pacific Russia and Northern Vietnam: notions, structural features, and types, Geogr. Nat. Resour., 2017, vol. 38, no. 4, pp. 333-340.

Böhnke-Henrichs, A., Baulcomb, C., Koss, R., et al., Typology and indicators of ecosystem services for marine 
spatial planning and management, J. Environ. Manage., 2013, vol. 130. pp. 135-145.

https://doi.org/10.1016/j.jenvman.2013.08.027

Braudel, F., Civilization and Capitalism, 15th-18th Century, Vol. 1: The Structure of Everyday Life, Berkeley, CA: Univ. of California Press, 1992.

Clarke, A.C., Towards a future Maritime Policy for the Union: A European Vision for the Oceans and Seas, Brussels: European Com., 2006.

Dergachev, V.A., Geopolitical theory of large multidimensional spaces, 2011. http://dergachev.ru/great_hour_of_the_oceans/06.html\#.XShywuszaUk. Accessed September 1, 2019.

Druzhinin, A.G., Large business in the coastal zones of Russia: factors and specific localization, Balt. Reg., 2019a, vol. 11, no. 4, pp. 136-151.

Druzhinin, A., The sea factor in the spatial and socioeconomic dynamics of today's Russia, Quaestiones Geogr., 2019b, vol. 38, no. 2, pp. 91-100.

Druzhinin, A.G., The strongholds of Russian coastal borderlands: economic dynamics amid geopolitical turbulence, Balt. Reg., 2020a, no. 3, pp. 89-104.

Druzhinin, A.G., "Marine component" of the socioeconomic geography in modern Russia: basic approaches and concepts, Geogr. Vestn., 2020b, no. 2 (53), pp. 24-37.

Druzhinin, A.G. and Lachinskii, S.S., Russia in the World Ocean: geoeconomic and geopolitical interests, scale, and "presence" formats, Izv. Russ. Geogr. O-va, 2019, vol. 151 , no. 6 , pp. $1-19$. https://doi.org/10.31857/S0869-607115161-19

Fardella, E. and Prodi, G., The belt and road initiative and its impact on Europe, Valdai Pap., 2018, no. 82, Mar. 28.

Fedorov, G.M. and Kuznetsova, T.Yu., The coastal microdistricts of the Baltic reigon: the spatial aspects of development, Ekon. Reg., 2019, vol. 15, no. 1, pp. 137-150.

Fedorov, G.M., Kuznetsova, T.Yu., and Razumovsky, V.M., The effect of the sea on the the economic development and settlement structure in the Kaliningrad oblast, Izv. Russ. Geogr. O-va, 2017a, vol. 149, no. 3, pp. 15-31.

Fedorov, G.M., Razumovsky, V.M., Kuznetsova, T.Yu., and Gumenyuk, L.G., Location and population dynamics of Baltic coastal cities, Izv. Russ. Geogr. O-va, 2017b, vol. 149, no. 6, pp. 14-24.

Fernández-Macho, J., González, P., and Virto, J., An index to assess maritime importance in the European Atlantic economy, Mar. Policy, 2016, vol. 64, pp. 72-81. https://doi.org/10.1016/j.marpol.2015.11.011

Foley, N.S., Corless, R., Escapa, M., et al., Developing a comparative marine socioeconomic framework for the European Atlantic area, J. Ocean Coastal Econ., 2014, vol. 1, no. 3 .

Gorshkov, S.G., Morskaya moshch' gosudarstva (Marine Power of the State), Moscow: Voenizdat, 1976.

Gudev, P.A., USA policy in the World Ocean, Mezhdunar. Protsessy, 2016, vol. 14, no. 1, pp. 106-120.

Kildow, J.T. and Mcllgorm, A., The importance of estimating the contribution of the oceans to national econo- mies, Mar. Policy, 2010, vol. 34, no. 3, pp. 367-374. https://doi.org/10.1016/j.marpol.2009.08.006

Kislovskii, V., On marine border, Morsk. Sb., 2009, vol. 1945 , no. 3, pp. 30-32.

Kurečić, P., The New Great Game: rivalry of geostrategies and geoeconomies in Central Asia, Hrvat. Geogr. Glas., 2010, vol. 72, no. 1, pp. 21-48.

Lachininskii, S.S. and Semenova, I.V., Sankt-Peterburgskii primorskii region: geoekonomicheskaya transformatsiya territorii (St. Petersburg Seaside Region: Geo-economical Transformation of the Territory), St. Petersburg: Lema, 2015.

Lachinskii, S.S., Lachinskii, A.S., and Semenova, I.V., Role of geoeconomic factor in the spatial structure development of the St. Petersburg coastal region, $I z v$. Russ. Geogr. $O-v a, 2016$, vol. 148, no. 2, pp. 52-67.

Lachinskii, S.S., Mikhailov, A.S., Samusenko, D.N., Mikhailova, A.A., and Sorokin, I.S., The role of coastal agglomerations and cities in the innovation space of the European part of Russia, Izv. Russ. Geogr. O-va, 2019, vol. 151 , no. 3 , pp. $1-17$.

Lee, S.-O., Wainwright, J., and Glassman, J., Geopolitical economy and the production of territory: the case of US-China geopolitical-economic competition in Asia, Environ. Plann., A, 2017, vol. 50, no. 2. https://doi.org/10.1177/0308518X17701727

Matishov, G.G., Denisov, V.V., and Dzhenyuk, S.L., Integrated environmental management in the northern seas, Izv. Ross. Akad. Nauk, Ser. Geogr., 2007, no. 3, pp. $27-40$

Murphy, A.B., Gérard Dussouy’s “systemic geopolitics," Geopolitics, 2010, vol. 15, no. 1, p. 151.

Park, K.S. and Kildow, J.T., The Estimation of the Ocean Economy and Coastal Economy in South Korea, Monterey, CA: Center Blue Econ., Monterey Inst. Int. Stud., 2014.

Payette, A. and Sun, T., China's two ocean strategy: controlling waterways and the New Silk Road, Asia Focus, 2017, no. 31.

Pilyasov, A.N. and Putilova, E.S., New projects for the development of the Russian Arctic: space is important, Arkt. Sever, 2020, no. 38, pp. 21-43.

Rybokhozyaistvennyi kompleks Primorskogo kraya. Sbornik s analiticheskoi zapiskoi (Fishery Industry of Primorsky Krai: Handbook with Analytical Note), Vladivostok: Primorskstat, 2018.

Savitsky, P.N., Kontinent Evraziya (Eurasia Continent), Moscow: Agraf, 1997.

Semyonov-Tyan-Shansky, V.P., O mogushchestvennom territorial'nom vladenii primenitel'no $k$ Rossii (The Powerful Territorial Possession in Relation to Russia), Petrograd: Tipogr. M.M. Stasyulevicha, 1915.

Shuper, V.A., Eurasian future of Russia in the terms of the alternation of integration and disintegration cycles, Balt. Reg., 2016, vol. 8, no. 4, pp. 7-17.

Smith, L.C., The World in 2050: Four Forces Shaping Civilization's Northern Future, London: Plume, 2011.

Song, W.L., He, G.S., and McIlgorm, A., From behind the Great Wall: the development of statistics on the marine economy in China, Mar. Policy, 2013, 
vol. 39 , pp. $120-127$.

https://doi.org/10.1016/j.marpol.2012.09.006

Sparke, M., Geoeconomics, globalisation and the limits of economic strategy in statecraft: a response to Vihma, Geopolitics, 2018, vol. 23, no. 1, pp. 30-37.

Stojanovic, T.A. and Farmer, C.J., The development of world oceans \& coasts and concepts of sustainability, Mar. Policy, 2013, vol. 42. pp. 157-165. https://doi.org/10.1016/j.marpol.2013.02.005

Suárez de Vivero, J.L. and Rodríguez Mateos, J.C., The Spanish approach to marine spatial planning. Marine Strategy Framework Directive vs. EU Integrated Maritime Policy, Mar. Policy, 2012, vol. 36, no. 1, pp. 18-27. https://doi.org/10.1016/j.marpol.2011.03.002

Suárez de Vivero, J.L. and Rodríguez Mateos, J.C., Forecasting geopolitical risks: Oceans as source of instability, Mar. Policy, 2017, vol. 75. pp. 19-28.

Surís-Regueiro, J.L., Garza-Gil, M.D., and Varela-Lafuente, M.M., Marine economy: a proposal for its definition in the European Union, Mar. Policy, 2013, vol. 42, pp. 111-124. https://doi.org/. 2013.02.010 https://doi.org/10.1016/j.marpol

The Ocean Economy in 2030, Paris: OECD, 2016. https://doi.org/10.1787/9789264251724-en

Treivish, A.I., Russian geopolitics from Gostomysl to the present: a brief overview of concepts and facts, ZnanieSila, 1995, no. 8, pp. 5-16.

Tridtsatye gody. Utverzhdenie evraziitsev (Thirties: Assertion of the Eurasians), Paris, 1931, book 7.

Vardomsky, L.B., The Northern Sea Route as a mechanism to ensure the connectivity with Great Eurasia, Mir Peremen, 2019, no. 2, pp. 129-140.

Voitolovsky, G.K., Development dynamics, in Teoriya $i$ praktika morskoi deyatel'nosti (Theory and Practice of Marine Activities), Moscow: Sov. Izuch. Proizvod. Sil, 2005, no. 5.

Zhang, Y., Wang, G., Liu, K., et al., A study on the characteristics of regional differentiation in China's marine economy and demarcation of marine economic areas, Econ. Geogr., 2015, vol. 35, no. 9, pp. 87-95. 